Caligrama, Belo Horizonte, v.20, n.1, p. 33-52, 2015

\title{
A leitora de romance-folhetim em $O$ tempo e o vento
}

\section{The reader of serial novel in $\mathrm{O}$ tempo e o vento}

\author{
Márcio Miranda Alves \\ Universidade de Caxias do Sul (UCS), Caxias do Sul, Rio Grande do Sul, Brasil \\ mirandaalves@gmail.com
}

Resumo: Este artigo analisa a presença das leitoras de romance-folhetim na trilogia $O$ tempo e o vento, de Erico Verissimo. Em $O$ retrato e $O$ arquipélago, as personagens Mariquinhas Matos, Emerenciana Amaral e Dona Vanja acompanham com grande expectativa a publicação de obras que aparecem nos jornais nas primeiras décadas do século XX. Essa leitura influencia as relações pessoais das personagens, que confundem realidade e ficção e reproduzem o vocabulário das histórias em Santa Fé. Nessa representação, a corrente literária popular, identificada com as leitoras de melodramas, contrasta com a corrente erudita, aberta a novos modelos estéticos. Como aporte teórico emprega-se Gramsci (1978) e Morin (1967).

Palavras-chave: romance-folhetim; literatura popular; leitura; Erico Verissimo.

Abstract: This article analyzes the presence of serial novel readers in the trilogy $O$ tempo e o vento, by Erico Verissimo. In $O$ retrato and $O$ arquipélago the characters Mariquinhas Matos, Emerenciana Amaral and Dona Vanja follow with great expectation the publication of works that appear in newspapers in the early decades of the twentieth century. This reading influences the personal relationships of the characters that confuse reality and fiction and reproduce the vocabulary of the stories in Santa Fe. In this representation the popular literary trend, identified with the readers of melodramas, contrasts with the erudite literary trend, open to new aesthetic models. As a theoretical approach is employed Gramsci (1978) and Morin (1967).

Keywords: serial novel; popular literature; reading; Erico Verissimo.

eISSN: $2238-3824$

DOI: $10.17851 / 2238-3824.20 \cdot 1.33-52$ 
Recebido em 07 de novembro de 2014.

Aprovado em 05 de junho de 2015.

\section{Introdução}

A representação das práticas de leitura na Santa Fé de $O$ tempo e o vento inclui, entre outros aspectos, o interesse das leitoras pelo romance-folhetim. $\mathrm{Na}$ perspectiva das personagens femininas, os romances seriados significam uma das poucas opções de leitura de ficção, visto que a circulação de livros é restrita e em geral um privilégio dos homens. Nesse mundo imaginário criado por Erico Verissimo os jornais não servem apenas aos homens, mais interessados no conteúdo político e ideológico. A paixão das leitoras pelo folhetim mostra que existe um público interessado em outros temas. E, se os periódicos são capazes de fomentar a curiosidade dos leitores sobre os assuntos da política, também podem exercer uma influência parecida junto às leitoras em questões de âmbito sentimental.

Em Santa Fé os romances de folhetim são recebidos por um público formado por faixas etárias, condição civil e estratos sociais diferentes, como a moça solteira de bom dote, Mariquinhas Matos, a mulher do coronel, Emerenciana Amaral, e a velha costureira e doceira, Dona Evangelina Mena, a Dona Vanja. Nesse quadro destaca-se a figura de Dona Vanja, uma das mais carismáticas do romance por conta de sua excêntrica mania de falar como as personagens das histórias da ficção. Não obstante, o emprego de palavras e expressões como "despautério", "urbs", "anexim" e "transeuntes" não é uma exclusividade dela. A reprodução do vocabulário folhetinesco também tem reflexos sobre o comportamento de Emerenciana Amaral, que "por influência de suas leituras dos folhetins do Correio do Povo, [...] usava termos como doidivanas, tresloucados, adrede..." (VERISSIMO, 1956a, p. 212-213).

Estas duas são leitoras entusiasmadas de folhetins, mas apresentam diferenças significativas nos traços de personalidade. Dona Emerenciana age como matriarca da família e da sociedade, responsável pela boa educação dos filhos e netos e vigia do comportamento das mocinhas. Nos bailes, fiscaliza as danças e observa com desconfiança os caixeirosviajantes, aspirantes e tenentes, rapazes da cidade grande interessados em desfrutar as meninas indefesas do interior. Para Emerenciana, as 
moças dividem-se em "sérias" e "desfrutáveis", uma lição que certamente aprendera nos romances de amor e adultério acompanhados pelo jornal. A esposa do coronel Alvarino Amaral não tem nada de meigo e delicado, descrita como "baixa, muito gorda e cinquentona, com um buço grosso que era quase um bigode, o nariz achatado e cheio de protuberâncias, a lembrar na cor e na forma uma batata com casca [...]" (VERISSIMO, 1956a, p. 211-212).

Dona Vanja, por sua vez, é do tipo que chora sempre que recita um poema trágico, descrita pelo narrador como "uma velhinha muito asseada, com cara de querubim, cabelos completamente brancos, pele rosada e olhos claros"(VERISSIMO, 1956b, p. 58). Quanto a Mariquinhas Matos, esta tem uma participação bem restrita na trilogia e o narrador pouco se ocupa em descrever o seu temperamento. A personagem costuma ficar à janela de casa, observando a vida passar, sempre à espera de uma proposta de casamento.

Apresentadas as personagens leitoras, vejamos a seguir como o romance-folhetim insere-se na tradição literária ocidental e, por consequência natural, brasileira, passando pelo escritor francês Émile Richebourg, para posteriormente podermos interpretar a representação desse universo em $O$ tempo e o vento.

\section{O folhetim e os dramas da vida}

Como bem lembra Gramsci (1978, p. 104), o romance-folhetim foi no século XIX até meados do XX um meio eficiente de difusão do jornal entre as classes populares, o que garantia sucesso político e financeiro ao empreendimento. O romance representante das "belasletras" também poderia figurar em suas páginas, desde que contribuísse para o aumento de receita. Nesse sentido, ao se analisar a influência dos folhetins na vida literária, seja sobre os escritores ou os leitores, é preciso ter em conta que, do ponto de vista do diretor do jornal, o leitor era apenas um cliente que precisava ser agradado para continuar consumindo o produto de uma forma permanente.

Na acepção de Meyer (1996, p. 64-65), o tempo histórico do romance-folhetim está intrinsecamente ligado à organização operária e aos movimentos armados que eclodiram na Europa dentro de um contexto reacionário da classe laboriosa. Por isso, as etapas de desenvolvimento do romance-folhetim podem ser divididas entre 1836-1850, 1851-1871 
e 1871-1914. Na primeira fase, a temática preponderante gira em torno do mistério e da vingança, dividida entre duas vertentes principais, o folhetim histórico e o "realista", este inspirado em eventos da vida cotidiana e ampliado pela imaginação do escritor; a segunda fase pertence ao rocambole, em que o herói do tipo "capa-e-espada" é o protagonista de diversas aventuras fantasiosas e dá origem ao termo "rocambolesco"; já na terceira, a que nos interessa em particular, o tema são os "dramas da vida", ou seja, a loucura, o abandono, o adultério, o crime, o amor, etc.

Neste longo período, segundo Morin (1967, p. 63-64), o romance popular de folhetim desperta interesses diferentes entre dois grupos sociais principais, tornando-se um centro de osmose entre a corrente popular, identificada com personagens da vida cotidiana empenhadas em aventuras "rocambolescas" e por vezes fantásticas, e a corrente burguesa, cujo imaginário funde-se no realismo. Essa diferenciação também se verifica na fidelidade da corrente popular aos temas melodramáticos (padrastos e madrastas, disfarces, identidades falsas, perseguição da inocência e substituição de crianças), enquanto a tendência burguesa é de preferência pelo conflito de sentimentos (dramas ou comédias triangulares do marido, do amante e da adúltera). De regra, essas duas correntes se misturam tanto na produção ficcional quanto na leitura do jornal pelos leitores populares, "onde dominam os leitores pequeno-burgueses ainda mal libertados das raízes populares, mas já semi-encaixados na cultura burguesa". Nas palavras de Morin:

$\mathrm{O}$ folhetim cria um gênero romanesco híbrido, no qual se acham lado a lado gente do povo, lojistas, burgueses ricos, aristocratas e príncipes, onde a órfã é a filha ignorada do príncipe, onde o mistério do nascimento opera estranhas permutas sociológicas, onde a opulência se disfarça em miséria e onde a miséria chega a opulência; a vida cotidiana é transformada pelo mistério, as correntes subterrâneas do sonho irrigam as grandes cidades prosaicas, o reboliço do desconhecido submerge as noites das capitais, aventureiros desenfreados reinam sobre as sombras da cidade, mendicantes e vagabundos. Desse estranho casamento do realismo e do onirismo nascem admiráveis epopeias populistas [...]. (MORIN, 1967, p. 64) 
Assumindo logo uma função lúdica, como defende Serra (1997, p. 23-25), o romance-folhetim atende mais a uma necessidade de divertimento do que de reflexão, consistindo em um gênero popular por excelência. Do ponto de vista do leitor, ou da leitora, havia um envolvimento grande em relação à história narrada. Ou seja, conhecer o romance que estava sendo publicado era uma espécie de "dever mundano" e cada capítulo gerava discussões em que se procurava expor uma intuição lógica ou psicológica dos eventos da ficção. Na avaliação de Gramsci (1978, p. 105), transpondo a observação para o ambiente da Itália, "pode-se afirmar que os leitores do romance de folhetim se interessam e se apaixonam pelos seus autores com uma sinceridade muito maior e com um interesse humano muito mais vivo do que, nos chamados salões cultos, as pessoas se interessam pelos romances de D'Annunzio ou pelas obras de Pirandello".

A penetração do folhetim também tem como destaque a inclusão da mulher no campo da leitura literária, antes uma prática exclusiva dos homens por conta da linha editorial sisuda dos jornais ou pela simples censura a romances ditos imorais. Com a circulação dos romances populares, elas passam a ter um assunto em comum para discutir nos eventos sociais, uma vez que a falta de liberdade para outras atividades que não fosse a doméstica limitava as experiências do grupo feminino. É a leitora, a "sinhazinha", portanto, o destinatário "natural" do romance-folhetim (MEYER, 1996, p. 379), geralmente provinda das classes altas e que via no folhetim uma forma de "entretenimento". E, conforme destaca Velloso (2008, p. 223), quanto mais violento e cheio de trágicas peripécias fosse o enredo, maior era o impacto e a repercussão da história na vida cotidiana de poucos acontecimentos. "Ao conversar com as amigas e vizinhas sobre as vicissitudes amorosas da heroína ou a perfídia do galã, as mulheres envolviam a vida cotidiana na trama desses acontecimentos romanescos".

Embora os folhetins continuem ocupando as páginas dos jornais no século XX e até no século XXI, ' cada vez com menos força, eles já

\footnotetext{
${ }^{1}$ Alguns exemplos da permanência do romance-folhetim na imprensa são a publicação de $O$ galo de ouro, de Raquel de Queiroz, publicado na revista $O$ Cruzeiro, em 1950, e A muralha, de Dinah Silveira de Queiroz, em 1954, na mesma revista. O jornal Diário Catarinense, de Florianópolis, publicou entre 14 de janeiro 2012 e 19 de janeiro de 2013, sempre aos sábados, o romance Você sabe de onde eu venho, de Tabajara Ruas. A narrativa foi inspirada na participação do Brasil na II Guerra Mundial e a ação transcorre durante a campanha da Itália, na qual o Brasil participou com a Força Expedicionária Brasileira (FAB).
} 
dão sinais de declínio a partir de 1885. Hallewell (1985, p. 140) observa que essa queda ocorre quando os jornais percebem que o sensacionalismo na cobertura de casos reais poderia ser mais eficaz do que a ficção dos folhetins. Valendo-se da experiência de sucesso do "continua amanhã", a imprensa passa a explorar a investigação de assassinatos e julgamentos, que são narrados de forma seriada e romanceada. Nestes casos, a população acompanha diariamente, com expectativa, o desenrolar dos acontecimentos como se se tratasse de ficção. ${ }^{2}$

No Rio Grande do Sul, o forte conteúdo político-partidário dos periódicos gaúchos não significa a existência de uma relação direta entre a ideologia do jornal e o folhetim publicado, "de sorte que muitos dos folhetins divulgados num jornal liberal podem vir a ter espaço num jornal republicano" (HOHLFELDT, 2003, p. 51). Isso favorece a repetição de determinadas obras no contexto da província e a popularização de certos autores dentro de um longo período. Autores lidos nos anos 70 e 80 do século XIX continuam a ser apreciados pelo menos até a terceira década do século XX, caso de Xavier de Montépin, Paul Féval, Ponson du Terrail, Perez Escrich, Octave Feuillet, Louis Berger, Decourcelle, Jules Mary, Charles Mérouvel (Charles Chartier), Pierre Sales, Georges Ohnet, Georges Maldague (Josephine Maldague) e Émile de Richebourg, entre outros.

\section{Richebourg e A toutinegra do moinho}

Por sua presença em O tempo e o vento nas leituras da personagem D. Vanja, Émile de Richebourg (1833-1898) merece uma apresentação mais detalhada. Considerado por muitos como o autor que melhor representa o modelo estético do romance-folhetim, Richebourg escreveu várias obras do gênero, cuja publicação no Le Petit Journal "fazia aumentar de um dia para outro a tiragem para 100 mil exemplares"

\footnotetext{
${ }^{2}$ Pesavento (2008, p. 368) afirma que o jornal opera como uma antena de sensibilidade social e faz da banalidade do cotidiano um objeto de interesse. "A história vivida passa a ser esmiuçada, retrabalhada, torna-se presença diária nas colunas dos diferentes jornais, mobilizando a população para acompanhar, cotidianamente, o desenrolar dos acontecimentos, como se a vida fosse transposta para as páginas dos jornais como um folhetim, a ser lido com gosto e expectativa. O jornal é, pois, capaz de transformar o vivido, o acontecido, aquilo que foi em uma peça literária, criando ambiência, emoção, razões e sensibilidades, em representações em que o critério da credibilidade suplanta o da veracidade".
} 
(MEYER, 1996, p. 212-213). Em revistas e jornais brasileiros foram publicadas traduções de obras como As duas rivais (Petite Mionne), A filha maldita, O filho dos operários ou a loucura da mãe, A louca, A viúva milionária e A toutinegra do moinho.

Gramsci (1978, p. 112), para o qual A toutinegra do moinho é "obra-prima do gênero que deve ainda resistir", situa as obras de Richebourg na categoria do tipo sentimental, "não político stricto sensu, mas no qual se exprime aquilo que se poderia definir como uma 'democracia sentimental"'. Essa "democracia sentimental" significa que a obra do escritor consegue envolver todo tipo de leitor(a), da lavadeira à burguesa da alta sociedade, exercendo uma grande influência moral sobre a sociedade ao abordar num mesmo romance questões sociais importantes e distintas quanto às relações entre capital e trabalho, condição feminina, nacionalismo e revolução.

Esse romance de Richebourg foi publicado pelo jornal Correio do Povo entre 1914 e 1915. Fundado em Porto Alegre em 1895, o Correio era já nesta época o principal jornal do Rio Grande do Sul, com alcance na maioria das cidades gaúchas. Para um grande público este jornal significou durante muito tempo a única alternativa de contato com a literatura e outras artes em geral. Além de publicar contos no Correio do Povo no início da carreira de escritor, Erico Verissimo também era leitor e colaborador do jornal. Para erguer o painel histórico de $O$ tempo e o vento, frequentemente recorria a consultas nas páginas do periódico, conforme revela em suas memórias (VERISSIMO, 1995, p. 303).

A trama do escritor francês inicia com a história de amor entre o tenente de artilharia Luciano de Lunière e a condessa de Morenne (Branca). Luciano parte para lutar na guerra entre França e México e fica mais de um ano ausente e sem dar qualquer notícia. Desesperançada com o futuro do relacionamento, Branca conhece o oficial de marinha Roberto de Serval e com ele se casa. Seis meses após o casamento Luciano regressa da guerra e reencontra Branca. Os dois continuam apaixonados e Branca acaba ficando grávida dele. A traição é descoberta por Roberto, que trata de arranjar um casamento para Luciano e obriga sua esposa a entregar a criança, um menino, para uma ama de criação.

O segundo drama vive o abastado João de Palizeul, primo de Branca e comandante de batalhão na Comuna de Paris. Com o fracasso do movimento, Palizeul é perseguido e foge com a filha Joana (a toutinegra) para a fronteira com a Bélgica. Hospedado em uma estalagem, acaba 
sendo roubado e gravemente ferido por Tomé Coplain, que acredita ter matado a vítima. De posse dos documentos pessoais de Palizeul, Coplain assume a identidade do outro. Com o sumiço do pai, a menina é adotada pela mesma ama que ficou com Jorge, filho de Branca e Luciano. As crianças crescem juntas e, com a morte da ama, são adotadas por um velho e bondoso lenhador. Joana e Jorge prometem nunca se separar, mas Jorge acaba voltando a Paris.

Para garantir o seu sustento e do lenhador, que não pode mais trabalhar, Joana começa a cantar nas praças e mansões. Sua beleza e talento para o canto encantam a todos, que passam a chamá-la de toutinegra do moinho, referência ao local onde mora com o lenhador. Numa dessas apresentações, na mansão de Coplain, este descobre que Joana é a filha de Palizeul (supostamente morto) e mantém a farsa, dizendo ser o pai da menina. No final, após muitas reviravoltas, Palizeul reaparece na história, localiza a filha e desmascara Coplain. Joana e Jorge reencontram-se, casam-se e vivem felizes para sempre.

Como se percebe, A toutinegra do moinho reúne os ingredientes que bem caracterizam o romance-folhetim da terceira fase, como a busca da protagonista por sua identidade, o abandono, a luta do bem contra o mal, o amor que supera todos os obstáculos, a manutenção do sistema de classes e a uma narrativa cheia de reviravoltas. Por sinal, essas reviravoltas não chegam a causar surpresa, pois é possível prever o que vai acontecer no capítulo a seguir. É como se o romance fornecesse exatamente aquilo que o leitor do drama espera ler. Outro aspecto da obra de Richebourg, e não exclusivo deste, é a mistura da ficção com dados da história. Em A toutinegra encontram-se informações sobre a guerra franco-prussiana, a intervenção francesa no México, a Comuna de Paris, as campanhas de colonização da Argélia e as galés da Nova Caledônia. Esses eventos históricos servem como um pano de fundo para o drama central.

\section{O popular e o erudito em Santa Fé}

Erico Verissimo não foi o primeiro escritor brasileiro a atentar para a importância do romance-folhetim na formação do público leitor e a explorar o tema na representação literária. Bem antes dele, Machado de Assis já fazia observações sobre essas leituras. Magalhães Jr. (1958, p. 143-152) aponta que o romance de aventuras Saint-Clair das Ilhas ou os desterrados da ilha de Barra, de autoria de Mme de Mantolieu e 
publicado em três volumes pela Garnier em 1850 com tradução de A.V. de C. e Sousa, é um dos mais citados na obra machadiana. Em geral, destaca Magalhães Jr., Machado refere-se às obras folhetinescas com ironia, emitindo através das personagens opiniões que são suas.

Em Helena, no capítulo III, D. Úrsula está sentada em sua poltrona a ler um conto do Saint-Clair das Ilhas, "enternecida pela centésima vez com as tristezas dos desterrados da ilha de Barra". Ao que o narrador acrescenta: "boa gente e moralíssimo livro, ainda que enfadonho e maçudo, como outros de seu tempo" (ASSIS, 1997, p. 282). Além destes, ainda conforme pesquisa de Magalhães Jr., também é possível encontrar na ficção machadiana referências a Visconde d'Arlincourt, Feydeau, Ernest Aimé, Octave Feuillet, Madame Craven, Alexandre Dumas e Le Sage, alguns dos autores mais traduzidos e publicados na imprensa carioca nessa época.

Em O tempo e o vento, o tema do folhetim surge no episódio "Chantecler", que se passa em 1910, em que o protagonista da narrativa é o jovem idealista Rodrigo Cambará. Na primeira situação em que o assunto é colocado pelo narrador, os representantes da alta sociedade de Santa Fé participam do baile de réveillon. Considerando-se o mais desejado pelas moças solteiras da cidade, o mais culto e bem vestido, Rodrigo dança com as filhas dos principais estancieiros. Na vez de Mariquinhas Matos, a Gioconda, ele tem uma oportunidade de esnobar seu repertório literário.

Dançaram num silêncio solene. E durante o intervalo entre as duas danças, conversaram animadamente. A Gioconda procurou mostrar-se muito culta e manter a palestra num nível elevado. Achava fúteis as moças de Santa Fé: só pensavam em vestidos, festas e bobagens. Ah! Ela tinha verdadeira paixão pela literatura. Lera as obras completas de Perez Escrich, adorava Eugène Sue, principalmente Os mistérios de Paris e achava Richebourg assim, assim. Ultimamente ficara muito impressionada com Os miseráveis de Victor Hugo. A propósito, como era hipócrita a sociedade que tolerava a até adulava os grandes ladrões, ao passo que levava para masmorras os miseráveis que roubavam uma côdea de pão para mitigar a fome! Rodrigo escutava-a com polida atenção, fazendo sinais de aprovação com a cabeça, mas achando a Gioconda supinamente ridícula naquela sua exibição de "cultura". Quando ela lhe deu uma oportunidade, desandou a falar 
nos seus autores de cabeceira. E atirou sobre a moça um punhado de nomes esmagadores: Taine, Renan, Anatole France, Verlaine, Rostand... A Gioconda sacudia a cabeça, com uma expressão de perplexidade nos olhos aveludados. Não conhecia nenhum daqueles escritores. Que romances tinham escrito? Ah... Espere. Esse Rostand não foi o que escreveu Os mistérios do Palais Royal?

- Não - respondeu Rodrigo. - Que eu saiba, Rostand não escreveu nenhum romance. (VERISSIMO, 1956a, p. 247-248)

Por trás da postura arrogante de Rodrigo, a cena coloca em lados opostos dois tipos de cultura, a popular e a erudita, representados pela leitora do romance-folhetim e pelo leitor de obras de outras qualidades, nos termos colocados por Morin (1967, p. 63-64). Gioconda representa o grupo de mulheres para as quais a literatura restringe-se à ficção que trata dos dramas da vida, à qual tinham acesso. Para ela a erudição significa ler e comentar as grandes obras melodramáticas do romancefolhetim. Já o protagonista pertence a outro estrato social e precisa portar-se como tal. Apesar de sua formação ter sido baseada na leitura de obras do mesmo gênero, como se pode constatar em suas memórias de infância, Rodrigo procura demonstrar superioridade intelectual - o que passa necessariamente pela superação dos romances preferidos das mocinhas. Afinal, acaba de voltar de Porto Alegre com o título de doutor e traz na bagagem mais de 500 livros franceses.

Mariquinhas Matos também aparece como a leitora que fica presa aos gostos do passado e apresenta dificuldade para se adaptar à moda literária. Por ocasião de outro baile de réveillon, este em 1922 no episódio "Um certo Major Toríbio", ela dança com o fiscal de imposto de consumo, natural de Belém, o qual está por dentro da última novidade: a poesia modernista. Este é o trecho:

Gioconda procurou exibir cultura. Assinava o Para Todos, deliciava-se com os "almofadinhas" e as "melindrosas" desenhadas por J. Carlos e adorava as crônicas de Álvaro Moreyra. Seu poeta predileto era Olegário Mariano declarou ela ao fiscal. Já leu As últimas cigarras? O moço não tinha lido.

- Prefiro poesia moderna, senhorita.

- Ora, nem diga! 
O fiscal era exímio no passo de camelo. A propósito dum pierrô cor-de-rosa, que fazia piruetas no meio do salão, a Gioconda recitou ao ouvido do par:

Sob a pele de alvaiade

Pierrô tem alma também

Não compreende o que é saudade

Mas tem saudade de alguém.

Enlaçando com a mão direita a cintura de Mariquinhas e com a esquerda segurando o lança-perfume e irrigando com heliotrópio o longo pescoço da moça, o paraense atacou Olegário Mariano e os outros poetas passadistas. Eram os homens dum mundo que morria - disse. - Convencionais, acadêmicos, artificiais. A Srta. Maria devia voltar-se para as vozes novas e originais que se erguiam no Brasil e no resto do mundo, na era dinâmica e vertiginosa do rádio, do automóvel e do avião!

A Gioconda sorria, encolhia-se, de olhos cerrados. Quando a música parou por um instante, o fiscal arrastou sua castelã para a área aberta do clube, sentou-se com ela a uma mesa, pediu cerveja e depois, com bolhas de espuma no bigode de galã, recitou-lhe em meio do pandemônio um poema de Oswald de Andrade.

- Mas isso é loucura! - exclamou Mariquinhas Matos. Não tem metro, não tem rima, não tem nexo!

- Qual! É muito boa poesia! - sorriu o moço. - É questão da gente se habituar e nos desintoxicarmos do nosso olavobilaquismo. (VERISSIMO, 1963, 496-497)

Mariquinhas Matos demonstra estar atualizada em assuntos de cinema, haja vista a assinatura da revista Para todos,${ }^{3}$ mas continua atrelada aos gêneros literários considerados ultrapassados. Se anteriormente seus escritores preferidos da prosa eram os mestres do romance-folhetim, o

\footnotetext{
${ }^{3}$ A revista Para Todos foi criada em 1918 e nos primeiros oito anos dedicou-se exclusivamente ao cinema. Após 1926, amplia a variedade de expressões artísticas, voltando-se para o público feminino jovem. Na capa, trazia sempre fotos e desenhos de atores e atrizes. J. Carlos, lembrado por Gioconda, foi um dos principais ilustradores da época, tendo se destacado inicialmente na revista Careta. Nas palavras de Sodré (1983, p. 302), J. Carlos "realizou verdadeira análise e tipificação da sociedade carioca, além da crítica política e de costumes [...]".
} 
que aos olhos de Rodrigo Cambará já eram coisa superada, agora ela deleita-se com a poesia parnasiana de Olegário Mariano. ${ }^{4}$ No entanto, o prazer literário de Gioconda é novamente atropelado por uma novidade que vem para substituir o que um dia fora a moda. Desta vez, o narrador aproveita para introduzir o tema do Modernismo no ambiente de Santa Fé e realça a oposição entre leitura popular e erudita.

Voltando no tempo cronológico da narrativa, no episódio "A sombra do anjo", que transcorre em 1915, Dona Vanja trabalha para sustentar o sobrinho Chiru, a esposa e os dois filhos deste. Isso não significa necessariamente um sacrifício para a velhinha romântica, que anda às voltas com os seus folhetins e encontra neles motivos para encarar a vida com otimismo. Rodrigo Cambará, em suas reflexões, observa:

Tia Vanja, porém - sabia-o ele - vivia no sétimo céu. Conservara o "velocino de ouro" em casa, ganhara uma 'nora' e 'netos'. E, para cúmulo da felicidade, o Correio do Povo estava agora publicando o mais formoso, o mais edificante dos romances: A Toutinegra do Moinho (VERISSIMO, 1956b, p. 234-235).

Nessa época representada em $O$ tempo e o vento, o Correio do Povo circulava seis dias por semana, menos às segundas-feiras. $\mathrm{O}$ folhetim aparece geralmente no miolo do jornal, ocupando o rodapé em páginas variadas, dividindo espaço com as notícias da Primeira Guerra Mundial. Do mesmo autor, no mesmo jornal, foram publicados outros dois romances no período que vai de 1910 a 1930. Um deles em 1923, intitulado Os filhos da milionária, e outro em 1930, A irmãzinha dos pobres. $^{5}$

\footnotetext{
${ }^{4}$ Bosi (2004, p. 235) inclui Olegário Mariano (1889-1958) entre os escritores que, analisados de forma isolada em meio a uma apreciação geral negativa da geração parnasiana, tiveram "momentos de feliz expressão artística" e resistiram ao impacto do Modernismo. Especificamente sobre Olegário Mariano, Bosi afirma que este foi "o mais independente de todos" e que "perpetuando o verso tradicional até à morte, deu exemplo de um lirismo aberto e simples". O livro As últimas cigarras foi publicado em 1920. ${ }^{5}$ Segundo levantamento de Hohlfeldt (2003, p. 309) em jornais de Porto Alegre entre 1850 e 1900, Émile Richebourg foi nesse período o terceiro autor mais publicado nos folhetins da capital gaúcha, com um total de sete obras, atrás apenas de Xavier de Montépin, com oito, e Henrique Perez Escrich, com nove.
} 
Na narrativa de $O$ tempo e o vento, a morte de Emerenciana Amaral significa para Richebourg a perda de uma leitora assídua. Durante o velório, em meio a choros e lamentações, Dona Vanja aproxima-se de Rodrigo Cambará e faz o seguinte comentário:

- Que calamidade, meu filho... - murmurou ela, olhando para o caixão. E com doçura, quase a sorrir, acrescentou: - Coitadinha da Emerenciana, não vai poder ler o fim da Toutinegra do Moinho...

Rodrigo sorriu mas não pôde evitar que as lágrimas lhe viessem aos olhos. Bateu de leve na mão da amiga numa carícia silenciosa. (VERISSIMO, 1956b, p. 266)

Esse diálogo, embora curto, desperta uma série de novas reflexões no fluxo narrativo. Isso porque a morte de Emerenciana, o comentário inocente de Dona Vanja e outros acontecimentos do velório sensibilizam Rodrigo e revelam aspectos caros da personalidade do protagonista. Durante um passeio, ele e o padre Astolfo conversam sobre a finalidade da vida e participação do folhetim no cotidiano da sociedade.

- Vou lhe contar uma coisa, padre, que lhe dará uma ideia de como sou preso aos prazeres deste mundo, por menores que sejam. Tia Vanja me disse lá no velório que foi uma pena dona Emerenciana morrer sem ter visto o final do folhetim do Correio do Povo. Acho que a velhinha não disse nenhuma tolice. Viver é bom por causa duma série de coisas grandes e pequenas entre as quais está também o de ler a Toutinegra do Moinho. A ideia da morte me é tão desagradável que nem a certeza de ganhar o Céu me faria encará-la com menos horror.

- E o senhor já pensou alguma vez na morte... quero dizer, a sério, como uma coisa que the pode acontecer a qualquer momento, amanhã, depois... agora?

- Não. Para falar a verdade, tenho a impressão de que morrer é coisa que não pode acontecer a mim, Rodrigo Cambará. (VERISSIMO, 1956b, p. 270)

Entende-se desse diálogo que, para o protagonista, a leitura de $A$ toutinegra do moinho é uma "coisa pequena" da vida cotidiana, mas aceitável num contexto em que a felicidade não se restringe necessariamente a "coisas grandes". Para Rodrigo, a ideia da morte e o 
horror frente à possibilidade de a vida acabar a qualquer momento são verdades fortes demais para alguém cheio de planos a realizar, apegado aos prazeres da boa vida. A observação de Evangelina é codificada por Rodrigo Cambará como uma justificativa de redenção para os seus abusos pessoais, explícitos no adultério, no jogo e em outras luxúrias.

Além disso, na percepção de Rodrigo Cambará os romances de folhetim são indicativos de um nível intelectual inferior, mesmo que tenham feito parte de sua formação de leitor no passado. Essa postura revela a evolução do gosto literário do personagem, que salta dos romances de aventura para o romance naturalista e, posteriormente, para a filosofia francesa, e também sinaliza de forma irônica a postura soberba da burguesia, que procura referências na última moda estrangeira e menospreza o gosto popular, sempre associado às classes inferiores.

No episódio "Lenço encarnado", em que as personagens estão envolvidas numa agitação política agravada por uma revolução, Dona Vanja continua alheia aos eventos da realidade. Seu vocabulário folhetinesco, porém, inclui novas palavras:

[...] Grande ledora de novelas folhetinescas, falava difícil, empregava vocábulos e frases que a gente em geral só encontra em livros ou notícias de jornal. Era talvez a única pessoa em Santa Fé que usava palavras como alhures, algures e nenhures. Nunca pedia silêncio; sussurrava: Caluda! Quando queria estimular alguém, exclamava: Eia! Sus! - Caspité! era uma de suas interjeições prediletas. Para ela o povo era sempre turbamulta; mãe, genitora; vaga-lume, pirilampo; cobra, ofidio. Tinha seus adjetivos, advérbios, substantivos e verbos arrumadinhos aos pares. Aspiração nunca se separava de lídima. Massa sempre andava junto com ignara. E podia haver uma coisa preparada que não fosse adrede? (VERISSIMO, 1963, p. 306)

Sendo esta a segunda vez que o narrador descreve a origem do vocabulário peculiar de Dona Vanja, torna-se evidente a intenção de acentuar a influência do folhetim na personalidade da personagem. $\mathrm{O}$ caso de Dona Vanja com a literatura popular vai além de uma simples relação de gosto por este ou aquele gênero literário. O narrador apresenta a personagem sob um ângulo cômico, cujos trejeitos são descritos de uma maneira simpática, denotando mais inocência do que sátira. Aúnica resistência vem da personagem Maria Valéria, que censura a velhinha por 
suas roupas coloridas e a falta de senso do real. Nada a estranhar, uma vez que Maria Valéria tem por característica a praticidade, a seriedade e a disciplina.

Segundo a caracterização de Dona Vanja, todos os acontecimentos sociais passam a ter um sentido positivo, nunca trágico, e os dramas sempre devem acabar bem no final. Por isso, ela não se preocupa com o destino do sobrinho, que faz parte de uma coluna revolucionária durante a revolução gaúcha de 1923.

[...] Para ela, aquele movimento armado era apenas uma espécie de parada. Romântica, só via o lado glorioso das guerras. Recitava com frequência $O$ Estudante Alsaciano, sabia frases célebres de grandes generais da História. Sonhava com ver Chiru voltar da revolução feito herói, "feliz, coberto de glória, mostrando em cada ferida o hino duma vitória", - como dizia o poema. Não lhe passava pela cabeça a ideia de que seu querido sobrinho pudesse ser morto. (VERISSIMO, 1963, p. 306)

Neste caso, Dona Vanja parece ser influenciada também pelas leituras de romances históricos, obras em que a ação está recheada de feitos heroicos. Especificamente sobre $O$ estudante alsaciano, a referência a esse poema reforça a desconexão temporal da personagem. O poema do português Acácio Antunes (1853-1927) é uma espécie de declaração de amor à França e remete à ocupação da Alemanha na região da Alsácia. Ou seja, uma manifestação patriótica que nada tem a ver com a revolução gaúcha em curso. O comportamento de Vanja pode ser um reflexo prolongado da campanha pró-França que chega a Santa Fé durante a Primeira Guerra e está representada em $O$ retrato.

Em outra situação na narrativa, Dona Vanja revela que acompanha a publicação de mais um folhetim.

- Mas estou muito triste hoje... - murmurou.

- Que foi que aconteceu?

- Não leram então o Correio do Povo?

Flora teve um sobressalto.

-Alguma notícia ruim?

- Muito ruim. Morreu a Jacqueline Fleuriot.

- Quem? 
- Então não sabem? A personagem principal d'A Ré Misteriosa, que o Correio estava publicando em folhetim. Apareceu hoje o último episódio. O jovem causídico finalmente descobriu que a ré que ele defendia tão ardorosamente, por pura piedade, outra não era que sua própria genitora. Muito tarde, tarde demais! Com a saúde minada por tantas emoções, a pobre Jacqueline, depois de abraçar o filho, entregou a alma ao Criador.

Maria Valéria e Flora entreolharam-se. Uma revolução convulsionava todo o Estado, irmãos se matavam uns aos outros nos campos e nas cidades, e ali estava D. Evangelina Mena com os olhos cheios de lágrimas por causa d'A Ré Misteriosa. Era demais! Maria Valéria sentiu a necessidade de fazê-la voltar à realidade. (1963, p. 307)

A insistência do narrador em apontar a desconexão de Dona Vanja com a realidade poderia sinalizar um estado de demência da personagem. Não parece, no entanto, ser essa a intenção, muito embora sua insensatez possa levar a esse entendimento numa análise crítica nesse sentido. A dificuldade de Dona Vanja para separar a ficção da realidade colabora para caracterizar um determinado tipo de leitor(a), que, influenciado pela poesia e pela prosa folhetinesca, passa a considerar o cenário romanesco um mundo "possível". Para esta personagem, não há limites definidos entre o que acontece no universo de Santa Fé e nas histórias de Émile Richebourg e Alexandre Bisson, autor de A ré misteriosa ${ }^{6}$ A diferença é que a vida criada pelos romancistas é muito mais interessante e cheia de emoções do que a vida monótona e rotineira da pequena cidade.

Por ser uma personagem secundária, com poucas aparições na narrativa, torna-se difícil analisar de uma maneira mais profunda o perfil psicológico de Dona Evangelina. O que se pode concluir com

\footnotetext{
${ }^{6}$ Alexandre Bisson (1848-1912) escreveu diversos romances e peças teatrais de grande aceitação do público. Seu maior sucesso foi com o drama Madame X (1908), encenado com Sarah Bernhardt no papel principal e levado ao cinema em pelo menos dez produções. No Brasil, Madame $X$ foi publicado em folhetins com o título de $A$ ré misteriosa, aparecendo no Correio do Povo entre 1922 e 1923. O romance foi adaptado para a televisão e levado ao ar na TV Tupi em 1966, com o título de $A$ ré misteriosa, mesmo ano em que o cinema norte-americano apresenta uma nova produção, como Madame X, com a participação de Lana Turner, John Forsythe e Ricardo Montalban.
} 
certa autoridade é que ela representa em $O$ tempo e o vento o que seria a leitora-tipo do romance-folhetim publicado em jornal no início do século passado. Em um momento em que outros meios de comunicação já são uma importante alternativa para o público interessado em entretenimento, como o cinema e as revistas ilustradas, a senhora de mais idade, dona de casa, menos suscetível às transformações midiáticas e de menor poder econômico, mantém-se fiel ao folhetim. Isso, de certa forma, também acentua as tensões entre tradição e modernidade presentes em $O$ tempo e o vento.

Como o modelo seriado de publicação de romances praticamente desaparece dos jornais a partir dos anos 30, Dona Vanja representaria uma das últimas seguidoras do gênero. Além disso, o interesse pelo folhetim também valoriza o produto jornal na representação da sociedade da época, tanto na função lúdica quanto no elemento agregador entre campo e cidade. Enquanto os arautos da filosofia e da literatura realista amparam-se nos livros e revistas importados, os representantes de grupos sociais menos favorecidos continuam absorvendo o que podem do jornal noticioso.

\section{Conclusões}

Em O tempo e o vento, a representação da leitura de obras literárias passa necessariamente pelo romance-folhetim. No universo de Santa Fé, nas primeiras décadas do século XX, o acesso aos livros é restrito a poucos e as personagens têm como única alternativa a leitura de histórias publicadas de forma seriada nos jornais.

Pelas páginas do Correio do Povo, as personagens Dona Vanja, Emerenciana Amaral e Mariquinhas Matos deliciam-se com estórias que retratam os dramas da vida, cujas tramas giram em torno de casos de abandono, amor e traição. Entre seus autores preferidos estão Perez Escrich, Eugène Sue e Emile Richebourg, à época considerados os mestres do romance-folhetim e que de fato eram presenças constantes na imprensa gaúcha e brasileira.

Mariquinhas Matos, a mais jovem das três leitoras, gosta de mostrar erudição aos seus pretendentes. No entanto, o narrador trata de revelar sua posição de fragilidade frente a leitores que estão atentos às novidades literárias. Em 1910, Rodrigo Cambará acaba de voltar de Porto Alegre formado em medicina, gaba-se de sua fluência em francês 
e afirma ser leitor de Taine, Renan, Anatole France, Verlaine e Rostand. Mais adiante, já na década de 20, o fiscal de imposto de consumo declama versos de Oswald de Andrade, ataca o que chama de "olavobilaquismo" e expõe o fosso existente entre os leitores da corrente popular e da erudita.

Nesse contexto, Mariquinhas Matos representa a leitora que não consegue acompanhar as mudanças ditadas pelos novos tempos e que são impostas pela última moda absorvida dos grandes centros urbanos, seja São Paulo ou Paris. Na pequena Santa Fé as novidades custam a chegar e são trazidas por Rodrigo Cambará, de Porto Alegre, ou pelo fiscal do imposto, um viajante por necessidades da profissão. Versos sem metro e sem rima são tão estranhos quanto o avião, considerado uma afronta ao gaúcho que ainda tem no cavalo o seu principal meio de transporte.

As personagens Dona Vanja e Emerenciana Amaral encaram a leitura dos romances como um passatempo que transforma para melhor a vida monótona e cheia de privações para as mulheres da vila. Nas histórias melodramáticas elas tiram lições para a vida prática, principalmente no que toca a noções de moral e ética social. Se por um lado a influência do folhetim impede que as personagens enxerguem a realidade ao redor, confundido dramas reais com estórias de final feliz, por outro contribui para haver um equilíbrio na galeria de tipos da narrativa. Em outras palavras, a ingenuidade e a graça de Dona Vanja e Emerenciana Amaral fazem uma espécie de contraponto aos homens rudes e austeros, sempre preocupados com os problemas da política e prontos para uma eventual revolução.

Embora o narrador deixe transparecer em alguns momentos a intenção de ironizar a postura das leitoras, por conta de sua fragilidade frente à influência de dramas ficcionalizados em romances açucarados, não consegue evitar uma descrição carismática de suas relações com outras personagens. Afinal, a sociedade do início do século XX dispunha de poucas opções de bens culturais e o jornal era um meio eficaz de fazer com que a literatura chegasse até as famílias. Em $O$ tempo e o vento as leitoras de romance-folhetim fazem dessa prática uma maneira de integração ao lazer e ao entretenimento dentro de suas possibilidades, sem o compromisso de se preocupar com questões de valor estético. 


\section{Referências}

ASSIS, Machado de. Obra completa. Rio de Janeiro: Editora Nova Aguilar, 1997. v. 1.

BOSI, Alfredo. História concisa da literatura brasileira. 42. ed. São Paulo: Editora Cultrix, 2004.

GRAMSCI, Antonio. Literatura popular. In: . Literatura e vida nacional. Tradução Carlos Nelson Coutinho. 2. ed. Rio de Janeiro: Civilização Brasileira, 1978. p. 103-138.

HALLEWELL, Laurence. O livro no Brasil: sua história. Tradução Maria da Penha Villalobos e Lólio Lourenço de Oliveira. São Paulo: T. A. Queiroz; Editora da Universidade de São Paulo, 1985.

HOHLFELDT, Antonio. Deus escreve direito por linhas tortas: o romance-folhetim dos jornais de Porto Alegre entre 1850 e 1900. Porto Alegre: EDIPUCRS, 2003.

MAGALHÃES Jr., Raimundo. Ao redor de Machado de Assis: pesquisas e interpretações. Rio de Janeiro: Civilização Brasileira, 1958.

MEYER, Marlyse. Folhetim: uma história. 2. ed. São Paulo: Companhia das Letras, 1996.

MORIN, Edgar. Cultura de massas no século XX: o espírito do tempo. Tradução Maura Ribeiro Sardinha. Rio de Janeiro: Editora Forense, 1967.

SERRA, Tania Rebelo Costa. Antologia do romance-folhetim (18391870). Brasília: Editora Universidade de Brasília, 1997.

SODRÉ, Nelson Werneck. História da imprensa no Brasil. 3. ed. São Paulo: Martins Fontes, 1983.

VELLOSO, Monica Pimenta. Sensibilidades modernas: as revistas literárias e de humor no Rio da Primeira República. In: LUSTOSA, Isabel (Org.). Imprensa, história e literatura. Rio de Janeiro: Edições Casa de Rui Barbosa, 2008. p. 211-230.

VERISSIMO, Erico. O tempo e o vento II - O retrato. Porto Alegre: Editora Globo, 1956a. v. 1.

VERISSIMO, Erico. O tempo e o vento II - O retrato. Porto Alegre: Editora Globo, 1956b. v. 2. 
VERISSIMO, Erico. O tempo e o vento III - O arquipélago. Porto Alegre: Editora Globo, 1963. v. 2.

VERISSIMO, Erico. Solo de clarineta. 20. ed. São Paulo: Editora Globo, 1995. v. 1. 